\title{
Conceptualising 'Smart' and 'Green' Public Open Spaces; Investigating Redesign Patterns for Greek Cities
}

\author{
Aspa Gospodini*, Stella Manika \\ Department of Planning and Regional Development, University of Thessaly, Pedion Areos, 38334 Volos, Greece
}

Received April 21, 2020; Revised May 27, 2020; Accepted June 23, 2020

Copyright (C2020 by authors, all rights reserved. Authors agree that this article remains permanently open access under the terms of the Creative Commons Attribution License 4.0 International License

\begin{abstract}
This paper deals with improving the quality of public open space in densely built and declining inner city areas. It investigates the potentials of 'smart' and 'green' redesign of public open space for enhancing public realm and the quality of life. Smart redesign of public open space entails the transformation of public open space into an inclusionary intelligent civic arena which allows citizens to have both face-to-face contact and interaction, and virtual communication by means of free community electronic equipment of space and e-services. Green redesign includes the refurbishing of public open space using green technologies and energy saving elements and equipment. The paper explores the amalgamation of 'smart' and 'green' design approaches and the development of a dynamic 'smart \& green' public open space and networked communities as catalysts to handle declining inner city neighborhoods. The thinking behind this approach lies in the urgent need for transformation of unused and meaningless private plots into common semi-public open space within urban blocks in shrinking urban units. Accordingly, we argue that this need reflects a potential double gain, a win-win scenario for simultaneously (a) raising awareness of spatial disadvantages in central urban areas, and (b) enhancing quality of life. Thus, in a broader perspective, urban shrinking units will potentially become more attractive and will gain a stronger economic and social identity. The paper investigates redesign patterns for Greek cities and presents a pilot study for cities of Volos and Larissa.
\end{abstract}

Keywords Public Open Space, Smart Growth, Green Redesign, Greek Cities

\section{Introduction - Greek Cities; Development Process, Urban Morphology, and Spatial Disadvantages}

In the second half of the 20th century - in the '50s, '60s and '70s - the rapid economic growth of large Greek cities has been fueling extensive internal migration from agrarian districts towards urban areas. Large Greek cities have experienced rapid and under-regulated spatial expansion, often characterized by informal housing in urban periphery. For many decades, the urbanization process, that is, urban design and planning, has been confined to soft state interventions: On the one hand, as far as private land is concerned, urban development has been regulated only through building legislation while master plans were only controlling land uses and densities and determining the basic shape of the street system [1]. Minimal state intervention in conjunction with land divisions into small-sized private properties produced a step-by-step urban development process and not a holistic redesigning. This type of land division- literally a property-by-property urban design — was carried out often without much consideration of neighboring properties or/and structural spatial entities such as the street, the urban square, the urban block, or the larger area.

In this context, the landscape in contemporary Greek cities is predominantly characterised by 'over-fragmented' and 'collage-like' morphology [2], (see Figure 1). On the other hand, as far as public land is concerned, for many decades master plans have been providing Greek cities with minimum standards of public open spaces and public amenities (squares, parks, children playgrounds, and the like). Such a process of urban development can explain many of the spatial disadvantages in contemporary Greek cities: That is, inner city areas, structured by the perimeter 
urban block system, are characterised by high built densities, the inefficiency of parking spaces, shortage of public open spaces and green spaces, neglected or underused public spaces, (see Figure 2); and on top of these features, inner city areas frequently suffer from bad environmental conditions such as the 'urban heat island' effect [3].

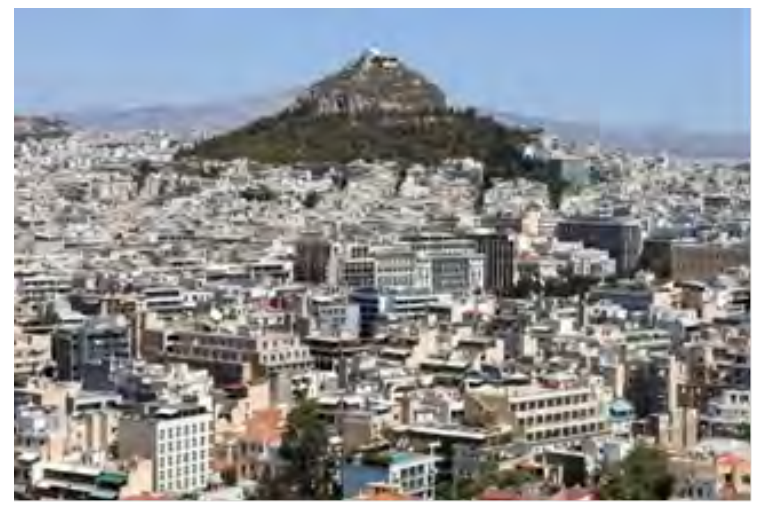

Figure 1. Athens; 'collage- like’ urban morphology

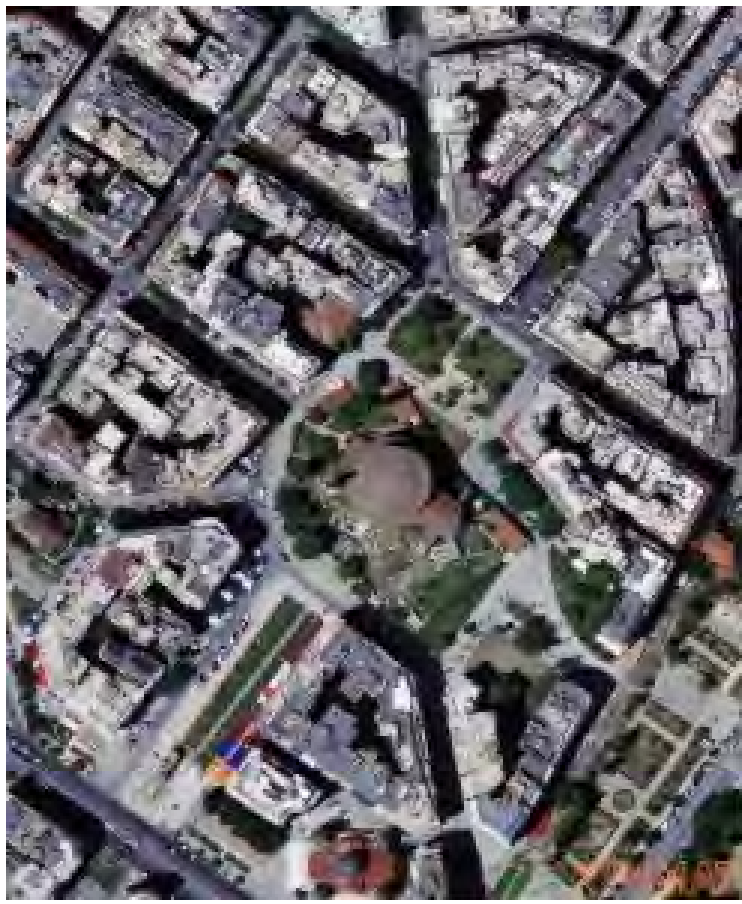

Figure 2. Thessaloniki; typical perimeter urban blocks and small green spaces

\section{Economic Crisis, Shrinking Cities and New Challenges for Urban Renewal}

Since 2008, the international economic crisis and the ongoing crisis of public depth in the Eurozone have had significantly negative spatial impacts on Greek cities. The hit on local urban economies, societies and space is widespread and clearly visible while there are strong indications that Greek cities have entered a phase of serious shrinkage: The closing down of small businesses (SMEs), mainly in the commercial and service sectors appears to spread rapidly in all Greek cities. For instance, in Thessaloniki, according to data provided by the Chamber of Commerce and Industry, a total of 16,990 businesses closed down during the last three years of the economic crisis. In inner city areas and the CBD (Central Business District) of Greek cities, a chain of vacant shops, offices, and houses can be observed in the formerly active and lively commercial streets.

In this context of recession and shrinkage, research conducted by the Lab of Urban Morphology, University of Thessaly (see [4]), has surveyed the spatial allocation of closed commercial shops in the center of Thessaloniki, Volos, Larissa, and Trikala. It is observed that as a consequence of the closing down of small businesses in inner city areas, there has been a radical devaluation of real estate properties. Interviews with real estate agencies about price comparisons between 2008 and 2012 have shown that in housing, for instance, the decrease of rents is about $30 \%$ while the devaluation of real estate prices varies between $40 \%$ and $50 \%$. The devaluation is stronger in office and commercial spaces than in houses and flats; it is also stronger in inner city areas than in the urban periphery. Overall research shows that the current conditions of low real estate prices have posed a new challenge and a chance for the local authorities to use abandoned buildings for public interest. More specifically, open space within urban blocks is usually over-fragmented into small private yards - empty and unused. In the perimeter blocks system, the expropriation and demolishment of one or two vacant buildings/ground floor spaces, could provide critical spatial links between open space within urban block and the street network surrounding it (see Figure 3).

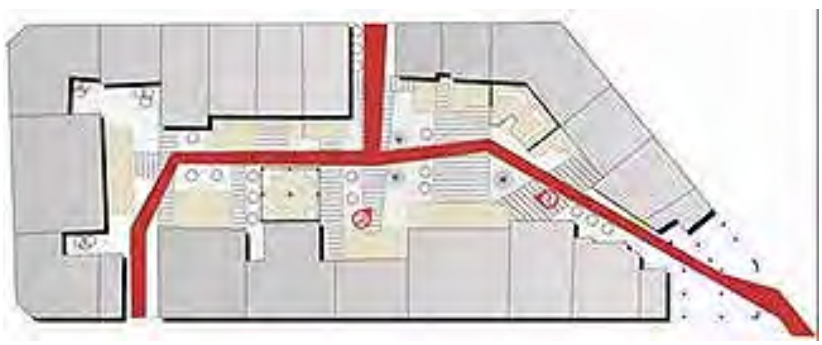

Figure 3a

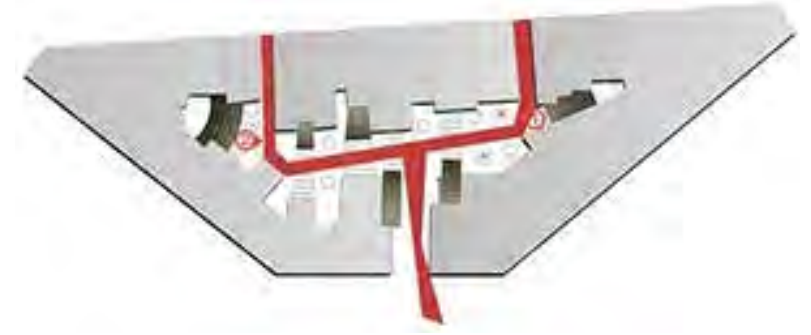

Figure 3b

Figure 3a and 3b. Typical perimeter urban block. Open space within blocks is usually over-fragmented, unused and meaningless. The expropriation and demolishment of a vacant building may provide a critical spatial link to the surrounding street network. 
This kind of intervention allows the transformation of meaningless interior open space into semi-public common gardens or parking spaces according to the precise 3-D formal characteristics and typology of the urban block. In certain types of urban blocks (see Figure 3a) which are constituted by middle-rise buildings (3-5 stores) and generate relatively wide interior open space with adequate sunlight, the creation of common gardens is practically achievable. In other types of urban blocks (see Figure 3b) which are constituted by high-rise buildings (6-8 stores) and generate relatively narrow and linear interior open space without adequate sunlight, the construction of common parking space is only feasible.

\section{Shrinking Areas as Front-Runners in the Transformation of Open Space Within Blocks - A Win-Win Scenario}

Achieving a high-efficiency transformation of unutilized inner open spaces is an inherently interdisciplinary endeavor and is thus structured around multiple points of convergence across urban planning, environmental psychology, and economic development [5]. Land use in the perimeter blocks system of nonfunctional interior open space is key for successful transformation. The process of 'smart' and 'green' regeneration importantly speaks to a renaissance in urban regeneration that calls for more healthy, resilient, and smart cities. This analysis turns to interior open spaces as core elements in the process of urban regeneration as interior open spaces have significant transformation potential, and at the same time engender strategies of promoting and achieving quality of life.

This research focuses on units where there is an abundance of unproductive open spaces and strong indicators of urban shrinkage. The thinking behind this approach lies in the urgent need for the transformation of unused private plots into a common semi-public open space within urban blocks in shrinking urban units. This need reflects the potential double gain, a win-win scenario for simultaneously (a) lifting spatial disadvantages of central urban areas, and (b) enhancing the quality of life of residents. In such processes of regeneration, urban shrinking units can potentially become more attractive and can gain a stronger economic and social identity, moving closer toward halting urban shrinkage.

Given that spatial units facing urban shrinkage are increasingly dispersed within the urban fabric, it was considered necessary to identify areas and to make a hierarchical classification combining their demographic and economic characteristics [6,7]. The multivariate analysis method of spatial patterns was used through weighted mapping overlapping thematic levels. Multivariate analysis, which decomposes the complex issue of urban shrinkage, was used as it can detect and analyze total and local structures, investigate and then classify [8] the urban blocks of the study area, Larissa, a typical medium-sized Greek city.

Urban shrinkage was first recognized and identified, and its definition variables (based on economic and demographic shrinkage trends) selected through (i) the literature [9-16] and (ii) the available data (sources: Larissa Chamber of Commerce and Hellenic Statistical Authority) examined over 7 years (2008 - 2014) [5]. More specifically, the variables selected are (i) the percentage change in business activity, (ii) racial proximity, (iii) dependency ratio, (iv) the percentage of unemployed, and (v) the percentage of the population who did not complete compulsory education. The dependency index is important for determining social and economic factors. The numerator includes the younger and older population (0-14 and $65+$ respectively) and the denominator includes the overall economically active population (15-64 years).

$$
A D R_{i}=\frac{\operatorname{Pop}_{(0-14), i}+\operatorname{Pop}_{(\geq 65) i}}{\operatorname{Pop}_{(15-64), i}} * 100
$$

This index, which reflects the number of economically dependent people in relation to the number of economically active people indicates the burden that the active population is receiving from the older and younger population. It, therefore, plays an important role in the study of urban shrinkage as the economically active population is what signifies a city's liveliness [17]. Further it is also an important factor that can contribute decisively to the possibility of renewing the conditions of a region.

The racial proximity index shows racial disparity, or the creation of ethnic enclaves in cities, as in many cases there is spatial segregation between citizens and immigrants [18].

$$
\text { AllPop_R }_{-}=\frac{A l l_{i}}{\text { Pop }_{i}} * 100
$$

Foreign or immigrant populations and communities are often considered the most vulnerable groups as they choose low-income areas of residence or otherwise precarious areas. In many cases, the presence of a high percentage of the foreign population is a sign of a deterioration or even abandonment of the residential stock [18].

The calculation of the "unemployment rate" index is carried out through the equation

$$
\text { UnempPer_ }_{-}=\frac{\text { UnempPer }_{\text {OEP }}}{\text { OEP }} 100
$$

where EAP is the Economically Active Population. This indicator was considered necessary as unemployment rates in a spatial unit have a decisive influence on rates of potential internal migration, which in turn can change the area of the establishment [19].

The index "percentage of the population that did not complete compulsory education" indicates the low quality of social and education programmes, an important parameter in deciding whether or not to change the bases of 
potential internal migrants and the aftermath such forms of migration can have on the structure of a region.

This multi-criteria analysis represents the system of values that consciously or subconsciously shapes the decisions taken by residents in specific areas. That is to say, an overall utility function identifies the individual utility functions and their properties in order to respond to problems with distinct alternatives, particularly when it comes to problems about decision-making and selection of areas. In some cases, multi-criteria analysis is used for the classification and categorization of alternatives. With regard to statistical weighting, the analytical hierarchical method was used in this article. That is, indicators for each different criterion were based on comparative/relative importance per group. The quantitative scales of classification were transformed into a single regular scale and the weighting, that is to say, the weighting factors were formulated to express the importance of each criterion. (The consistency index is acceptable as it is 0.0814857 $<0.1$. The suitability map created came from the transformation of each level into a binary map with a strict criterion and then its calibration based on the degree to which it relates to the phenomenon under consideration (Table 1).

Thus, the map produces a mosaic of frequent alternating urban blocks ranging from high to low concentration of signs of urban shrinkage (see Figure 4). This classification generates spatial patterns of urban blocks most vulnerable, economically, and demographically to the symptoms of urban shrinkage, which are areas most suitable for priority urban regeneration policies. Simultaneously, these vulnerable areas are considered a productive ground for urban renewal interventions on neighborhood-scale, as described in Figure 4. The multivariate analysis was used in a way that allowed the formulation of standardized procedures that make a decisive contribution to resolving the shrinkage phenomenon based on the link of the factors associated with it [20], via a unified approach.

Vacant buildings and underutilized spaces located in the spatial pattern on the vulnerability of the study area to shrinkage (Figure 5) have the potential to become key pillars for the development of new working styles and forms of sharing economy [22]. Coworking Spaces and WeWork's Business Model, promoting resource usage utility. Coworking spaces refer to co-located groups of independent workers (namely freelancers or remote workers) where members work in parallel [23]. WeWork's Business Model transforms the system beyond its co-working spaces and improves its efficiency including " $a$ creative atmosphere", big corporations, and high-profile tech enterprises [24]. Coworking spaces present a global spread with a concentration on "creative cities" [25] which are regarded as "serendipity accelerators" [26] and lead the way to "new forms of microclusters" to the local dynamics of knowledge creation and transfer [27]. Coworking spaces are theorized as microclusters given that they present similar characteristics to those of industrial clusters at the scale of the city [27].

Further, coworking spaces implicitly support interaction and the sense of community [23] by offering shared open spaces (physical or virtual) [25] and a focus on community building [28]. In addition, they make the interaction more effective and fruitful by coexisting with conventional office spaces. In light of this sense of connection strengthened by coworking places, which potentially renew existing low-profit urban spaces, this research applies a coworking approach to spatial patterns that indicate vulnerability to shrinkage in the study areas in order to promote sustainable development.

Table 1. Calibration Matrix

\begin{tabular}{|c|c|c|c|c|c|}
\hline & $\begin{array}{c}\text { Percentage change } \\
\text { in business activity }\end{array}$ & $\begin{array}{c}\text { Racial } \\
\text { Proximity }\end{array}$ & $\begin{array}{c}\text { Dependency } \\
\text { Ratio }\end{array}$ & $\begin{array}{c}\text { Percentage of } \\
\text { unemployed }\end{array}$ & $\begin{array}{c}\text { Percentage of the population who } \\
\text { did not complete compulsory } \\
\text { education }\end{array}$ \\
\hline $\begin{array}{c}\text { Percentage change in } \\
\text { business activity }\end{array}$ & 1 & 3 & 4 & 3 & 5 \\
\hline Racial Proximity & 1 & 3 & 2 & 4 \\
\hline Dependency Ratio & & & 1 & $1 / 4$ & 4 \\
\hline $\begin{array}{c}\text { Percentage of } \\
\text { unemployed }\end{array}$ & & & & & 1 \\
\hline $\begin{array}{c}\text { Percentage of the } \\
\text { population who did not } \\
\text { complete compulsory } \\
\text { education }\end{array}$ & & & & & \\
\hline
\end{tabular}




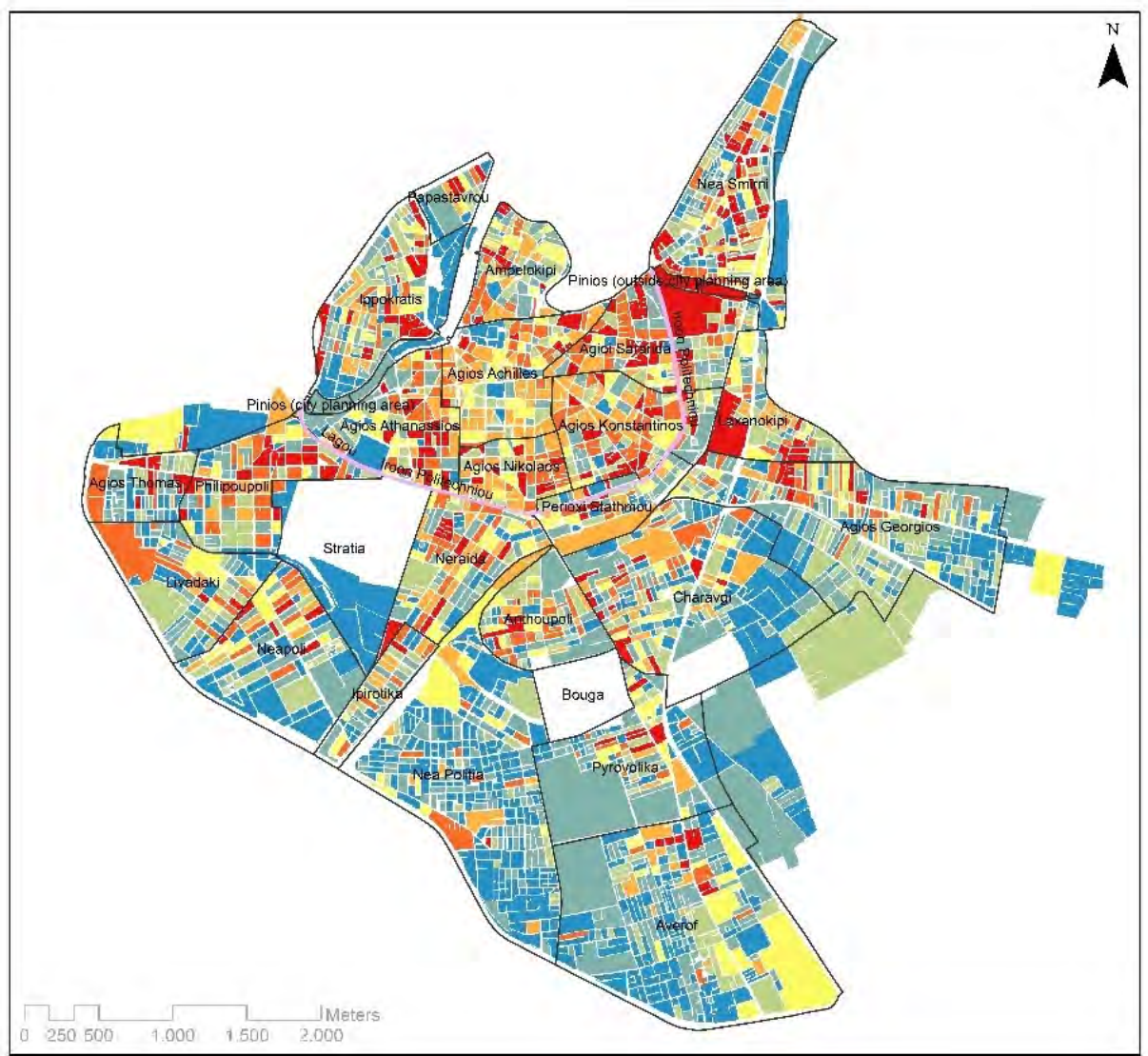

Suitability map

Areas most suitable for priority

urban regeneration policies

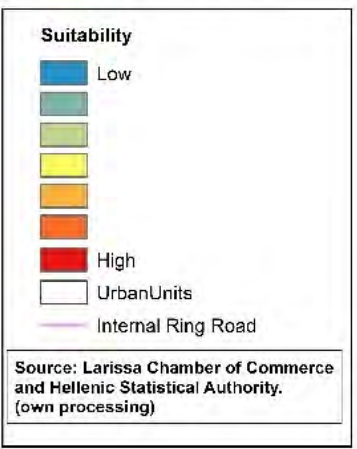

Figure 4. Classification of urban blocks ranging from high to low concentration of signs of urban shrinkage. Distinct spatial patterns of vulnerable areas

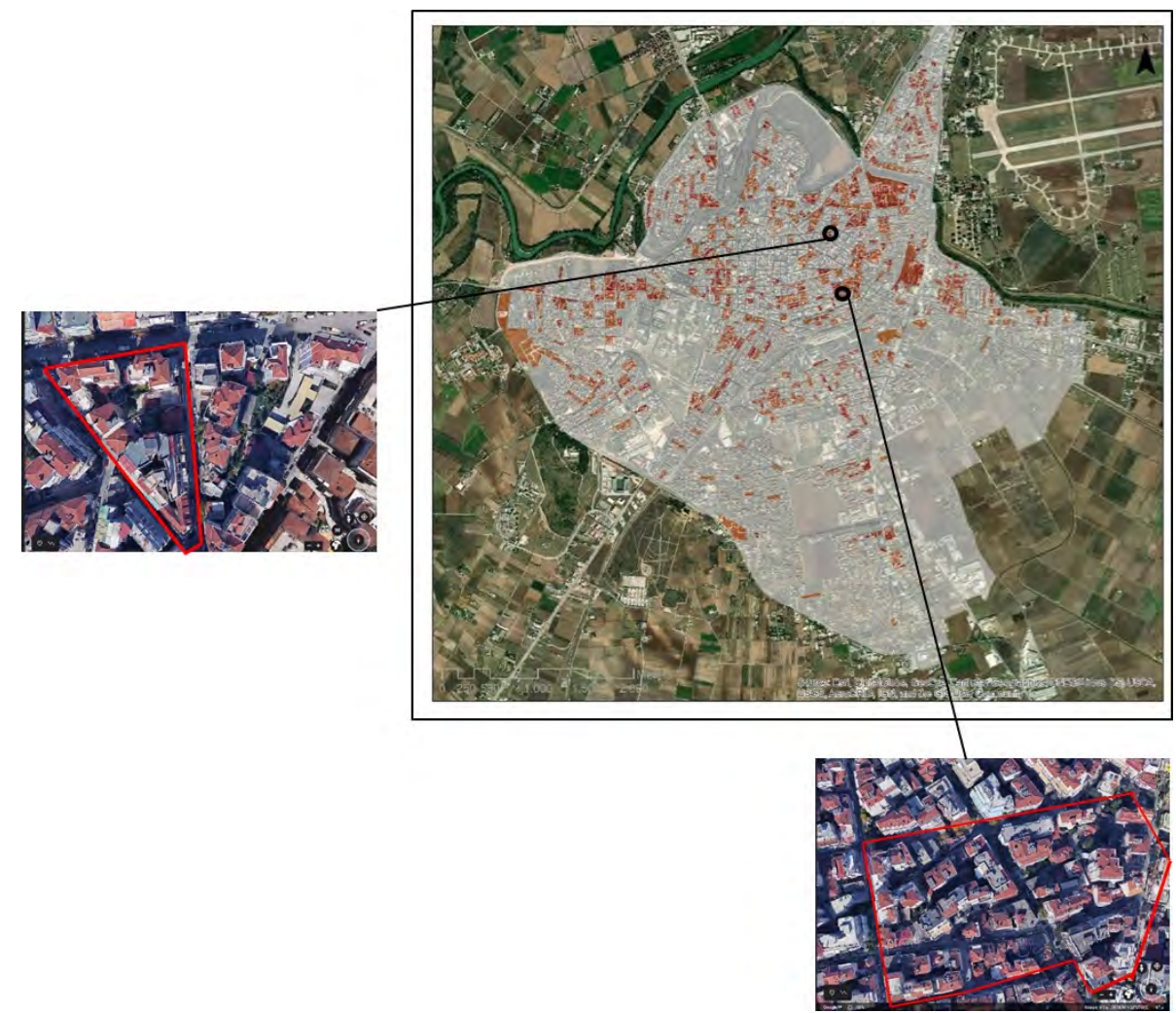

Figure 5. Typical perimeter urban blocks located in the spatial pattern of vulnerable to shrinkage areas. These blocks have potentials to become "superblocks", constructed cells transforming this area to compact and connected neighborhood - Barcelona superblock model, see [21]) 
Improving the quality of public open space in densely built and declining inner-city areas is the incentive behind the present study. The implementation of the proposed urban renewal interventions on neighborhood-scale in declining inner-city areas, as described in figures 6 and 7, add a new trend with regard to the scarcity of green space. The proposed active and green role of unproductive small private spaces will contribute to the increase of the percentage of green spaces, especially in Greek cities that have suffered from scarcity of public green spaces.

Increasing green spaces may lead to an improved quality of life, and other social and economic benefits mainly related to urban-based movement patterns and a new social interaction equilibrium within the neighbourhood. The implementation of the proposed network of smart and green public open spaces may have an impact on the decision of the upper-middle-classes not moving to peripheral or/and suburban units. The control of such a movement can be propelled by a new convivial environment with many advantages that the upper-middle-class would decide to benefit from.

Alongside the aforementioned beneficial effects of increasing urban sustainability and stimulating gentrification, the proposed urban renewal intervention can lead to social porosity in terms of the urban structure. In particular, the proposed high-quality designed public open spaces (playgrounds, skate parks, and main squares) can rebuild the neighborhood's social cohesion and sense of community. Smart-designed public open spaces will promote group activities embodying social interaction with peers. At the same time, urban farms will introduce a new perspective on consuming urban space with multivariate benefits, including access to fresh food.

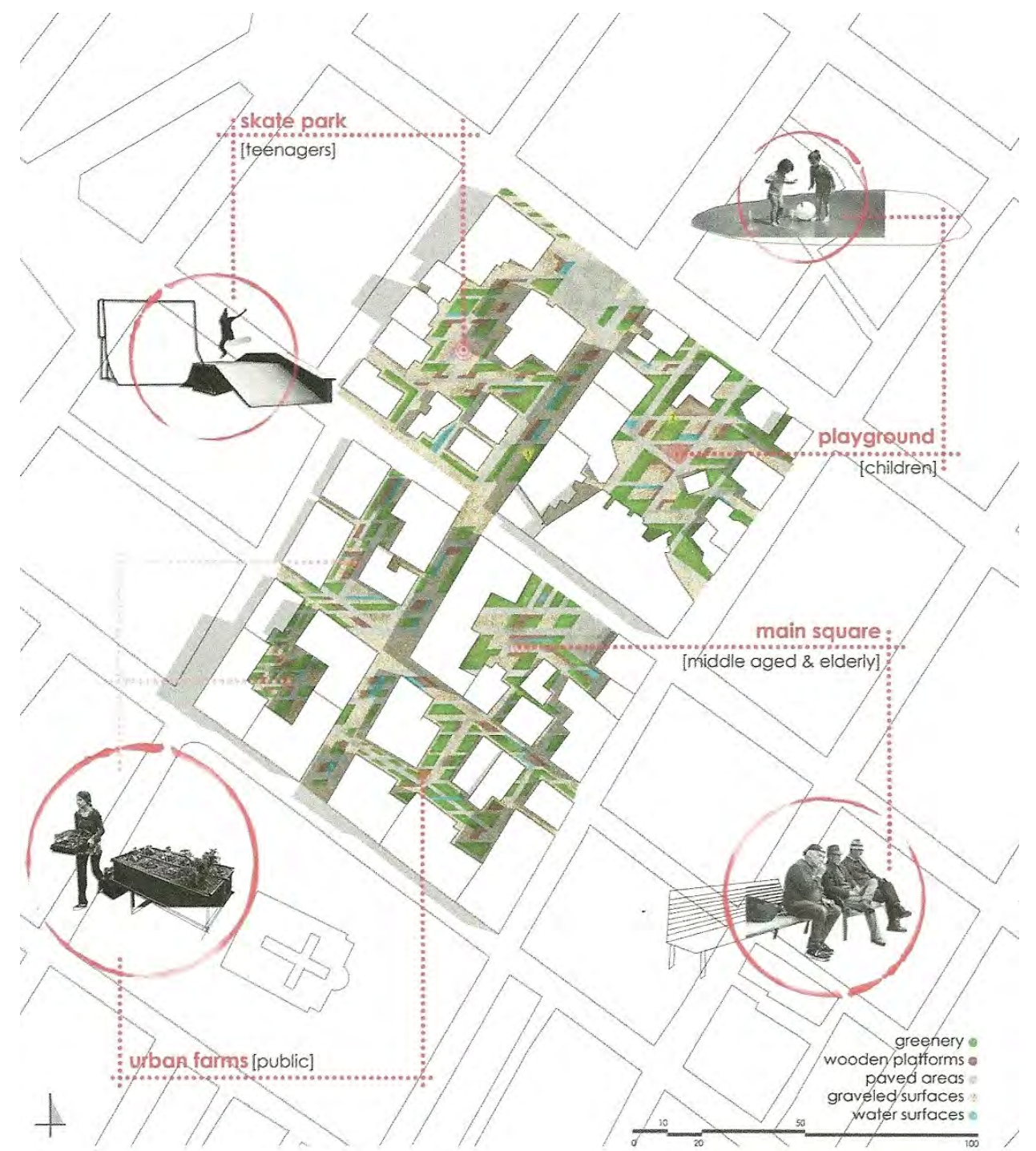

Figure 6. Implementation on neighborhood-scale in declining inner city areas can create a new network of differentiated public open spaces fitting into the divergent needs and value systems of postmodern urban societies 


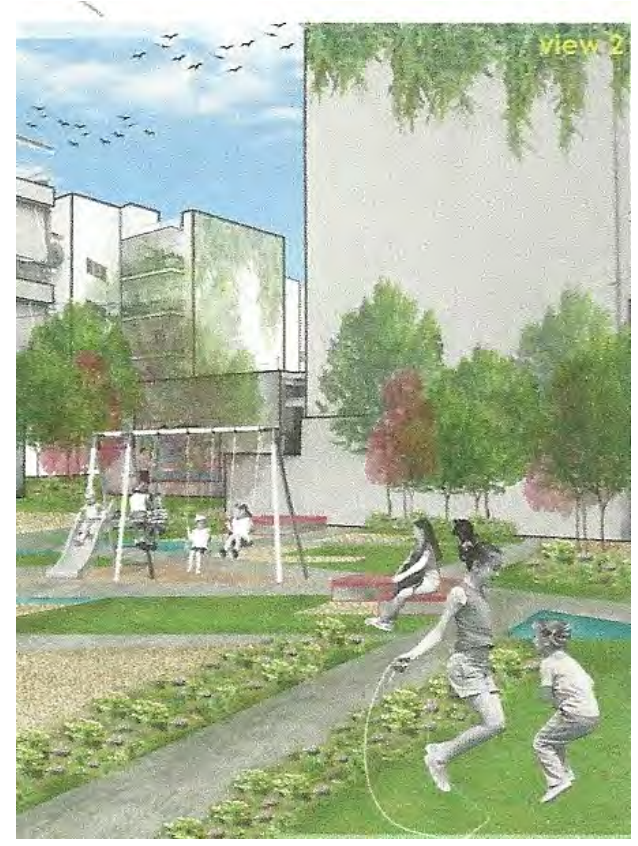

Figure 7. Green roofs and green vertical walls

\section{Conclusion - Investigating Networks of Smart and Green Public Open Spaces}

This investigation has been carried out in Lab of Urban Morphology, Department of Planning \& Regional Development, University of Thessaly by the authors of this paper, as part of a larger research on Urban Regeneration of inner-city areas in Greek cities. The implementation of such urban renewal interventions in declining inner-city areas on a neighborhood-scale may generate multifaceted positive outcomes on Greek cities. Such interventions importantly increase the percentage of public open space, green space, and parking space in densely built areas. Further, 'smart' and 'green' urban redesign can create a new network of differentiated public open spaces (e.g. traditional squares, skate parks, urban farms, etc., see Fig.6) which according to the principles of 'smart' and 'green' redesign (e.g. integrating Wi-Fi spaces for teenagers, kiosks with touch screen information, etc.) may encourage the creation of a smart environment, well-fitting into the diverse needs and value systems of postmodern urban societies. Other positive outcomes include potentially counteracting the 'urban heat island' effect and improving the environmental conditions especially if combined with green roofs and green vertical walls [3] (see Figure 7). Finally, such urban renewal interventions can contribute to the enhancement of the quality of urban space in inner-city areas thereby counteracting urban decline, stimulating gentrification, and increasing urban sustainability [29-31].

Considering the overall outcomes of 'smart' and 'green' urban regeneration, the creation of smart public open spaces appears to be of great importance since it involves new concepts of the public realm in contemporary informational societies. In recent literature, cyberspace is conceived as "a territory of freedom and lack of boundaries" [32] as well as "the fastest-growing territory in all of world history" [33], a field where human needs such as work, recreation, social interaction, information, and consumption may be met within new forms of societies [34]. Complementing the arguments enhancing the role of cyberspace, recent research [35] has suggested that although there has been a significant shift of public realm from physical space to virtual space due to the rapid development of ICT's and the fast growth of cyberspace, cities still represent successful configurations for the public realm in terms of communication, social interaction and recreation. Individuals appear to still prefer the city's public spaces to cyberspace. Yet a great new challenge emerges for planners and designers as cities need to upgrade their public spaces integrating by means of smart design the most attractive features and characteristics of cyberspace into their individual urban identities.

\section{REFERENCES}

[1] Emmanouil, D (1998). 'Minor Improvements in a Picture of Overall Immobility: an Economic Problem or a Political and Societal issue?', English summary of the Greek Article, in F Infussi and Y Simioforides (eds) Programma Heracles, Le sfide della citta greca, Athens: Linora, pp 206-217

[2] Beriatos E., Gospodini, A. (2004). "Glocalizing Urban Landscapes - Athens and the 2004 Olympics", in Cities 21(3): 187-202.

[3] Santamouris, M. (2006). Environmental Design of Urban Buildings: An Integrated Approach, Taylor \& Francis.

[4] Gospodini, A (2013). 'ECONOMIC CRISIS \& SHRINKING CITIES. Searching a path for addressing shrinkage in Greek cities', a paper presented at the international conference Changing Cities, Skiathos Island, Greece, 18-22 June.

[5] Manika, S. (2018). Economic crisis, Greek Shrinking Cities and Urban Regeneration Policies, University of Thessaly, Volos.

[6] Manika, S., Gospodini, A. (2015). "Economic downturn and urban landscape. Investigating urban shrinkage in a middle-sized Greek city-Larissa”, Plurimondi. An International Forum for Research and Debate on Human Settlements. Vol 7, No 15: The XIX European Colloquium in Theoretical and Quantitative Geography (ECTQG2015), Vol 7, No 15.

[7] Manika, S., Gospodini, A. (2016). Greek cities in the era of economic recession and crisis; Analysing business demography and portraying the emerging new urban landscapes, IV WPSC World Planning Schools Congress 2016, 3-8 July, Rio de Janeiro, Brazil.

[8] Freeman, R. E. (2010). Strategic Management: A 
Stakeholder Approach. University of Virginia.

[9] Haase, D., Haase, A., Kabisch, N., Kabisch, S., \& Rink, D. (2012). Actors and factors in land-use simulation: The challenge of urban shrinkage. Environmental Modelling \& Software, 35, 92-103. doi: 10.1016/j.envsoft.2012.02.012

[10] Schetke, S., \& Haase, D. (2008). Multi-criteria assessment of socio-environmental aspects in shrinking cities. Experiences from eastern Germany. Environmental Impact Assessment Review, 28(7), 483-503. doi: 10.1016/j.eiar.2007.09.004

[11] Reis, J. P., Silva, E. A., \& Pinho, P. (2015). Spatial metrics to study urban patterns in growing and shrinking cities. Urban Geography, 1-26.doi: 10.1080/02723638.2015.1096118

[12] Newman, G. (2013). A conceptual model for measuring neglect in historic districts. Journal of Preservation, Education, and Research, 6, 41.

[13] Murgante, B., \& Rotondo, F. (2013a). A Geostatistical Approach to Measure Shrinking Cities: The Case of Taranto. In S. Montrone \& P. Perchinunno (Eds.), Statistical Methods for Spatial Planning and Monitoring (pp. 119-142): Springer Milan.

[14] Lee, J., \& Newman, G. (2017). Forecasting urban vacancy dynamics in a shrinking city: A land transformation model. ISPRS International Journal of GeoInformation, 6(4). doi: 10.3390/ijgi6040124

[15] Hollander, J. B., Hartt, M. D., Wiley, A., \& Vavra, S. (2018). Vacancy in shrinking downtowns: a comparative study of Québec, Ontario, and New England. Journal of Housing and the Built Environment. doi: 10.1007/s10901-017-9587-9

[16] Hartt, M. D. (2016). How cities shrink: Complex pathways to population decline. Cities. doi: https://doi.org/10.1016/j.c ities.2016.12.005

[17] Guimarães, M. H., Nunes, L. C., Barreira, A. M. and Panagopoulos, T. (2016). 'What Makes People Stay in or Leave Shrinking Cities? An Empirical Study from Portugal'. European Planning Studies: 1-25. http://dx.doi.org/10.1080/09654313.2016.1177492.

[18] Anastasiou, E. (2018) Social and Economic Dimensions of the Rural Return during the crisis: quantitative and qualitative approaches, University of Thessaly, Greece

[19] Báov, N. (Ed.). (2007). (in Greek) $\Delta 1 \alpha \pi \lambda \varepsilon \kappa o ́ \mu \varepsilon v \varepsilon \varsigma$

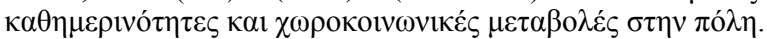

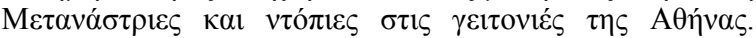
A $\theta \dot{n} v \alpha$

[20] Boroushaki, S.; Malczewski, J. Participatory GIS: A Web-based Collaborative GIS and Multicriteria Decision Analysis. Urisa J. 2010, 22, 23-32.

[21] Mueller, N., Rojas-Rueda, D., Khreis, H., Cirach, M., Andrés, D., Ballester, J., Bartoll, X., Daher, C., Deluca, A., Echave, C., Milà, C., Márquez, S., Palou, J., Pérez, K., Tonne, C., Stevenson, M., Rueda, S., \& Nieuwenhuijsen, M.
(2020). Changing the urban design of cities for health: The superblock model. Environment International, 134, 105132. https://doi.org/10.1016/J.ENVINT.2019.105132

[22] Huang, H., Liu, Y., Liang, Y., Vargas, D., \& Zhang, L. (2020). Spatial perspectives on coworking spaces and related practices in Beijing. Built Environment, 46(1), 40-54. https://doi.org/10.2148/benv.46.1.40

[23] Garrett, L. E., Spreitzer, G. M., \& Bacevice, P. A. (2014). Co-constructing a sense of community in coworking spaces. 74th Annual Meeting of the Academy of Management, 2014, 1015-1020. https://doi.org/10.5465/AMBPP.2014.139

[24] Roggero, R. (2019). Coworking spaces and the WeWork phenomenon. Luiss Guido Carli.

[25] Cabral, V., \& Van Winden, W. (2016). Coworking: An analysis of coworking strategies for interaction and innovation Collaborating with competitors to improve sustainability in denim production View project Knowledge Districts in Cities View project. https://doi.org/10.13140/R G.2.1.4404.5208

[26] Moriset, B. (2013). Building new places of the creative economy. The rise of coworking spaces. https://halshs.archives-ouvertes.fr/halshs-00914075

[27] Capdevila, I. (2014). Knowledge Dynamics in Localized Communities: Coworking Spaces as Microclusters. SSRN Electronic Journal. https://doi.org/10.2139/ssrn.2414121

[28] Oksanen, K., \& Ståhle, P. (2013). Physical environment as a source for innovation: Investigating the attributes of innovative space. Journal of Knowledge Management, 17(6), 815-827. https://doi.org/10.1108/JKM-04-2013-0136

[29] Ritchie, A., Randall Th. (2013) (eds) Sustainable Urban Design: An Environmental Approach. Taylor \& Francis.

[30] Von Hausen, M. (2013) Dynamic Urban Design. A handbook for creating sustainable communities worldwide. I Universe publications.

[31] Stremke, S., Van den Dobbelsteen, A. (2012) (eds) Sustainable Energy Landscapes: Designing, Planning, and Development. CRC Press, Taylor and Francis.

[32] Stevenson, D., 2003. Cities and Urban Cultures. Buckingham, UK and Philadelphia: Open University Press.

[33] Wertheim, M., 1997. The pearly gates of cyberspace. In: Ellin, N., ed. Architecture of fear. New York: Princeton Architectural Press

[34] Greinacher, U., 1997. Fear and dreaming in the American city: From open space to private space. In: Ellin, N., ed. Architecture of fear. New York: Princeton Architectural Press.

[35] Gospodini, A., Zachos, D. (2013) 'Public Space in Cities and Cyberspace. A comparative analysis guiding urban design and planning' a paper presented at 2013 Aesop annual congress, Dublin, 15-19 July 2013. 